\title{
Portrayal of Textile Based Pollutants and its Impact on Soil, Plants and Fisheries
}

\author{
M. Riza*†, M. N. Ehsan**and S. Hoque ${ }^{* * * *}$ \\ *Department of Environmental Science, Bangladesh University of Professionals, Dhaka, Bangladesh \\ **Department of Textile Engineering, Southeast University, Dhaka, Bangladesh \\ ***Department of Soil, Water \& Environment, University of Dhaka, Dhaka, Bangladesh \\ $\dagger$ Corresponding author: M. Riza; mumtahina@seu.edu.bd
}

Nat. Env. \& Poll. Tech.

Website: www.neptjournal.com

Received: 26-09-2020

Revised: $18-11-2020$

Accepted: 08-12-2020

\section{Key Words:}

Agriculture

Effluents

Fisheries

Textile Pollutants

Soil

Plants

\begin{abstract}
The textile industry occupies a significant hold on the global economy. This substantial industry often generates a large volume of effluents exceeding the permissible limit of discharge in the different regions of the world. Therefore, textile effluents act as pollutants altering the natural composition of various components of the environment. This paper discusses the impact of textile-based pollutants on agriculture including plants, soil, water and fisheries. The observed result is significant because textile effluents exert a widespread negative impact on the respective respondents, though plants show few positive effects. Prior treatment of textile wastewater is necessary before applying it to the soil, as there is a possibility of affecting the plant ecosystem via soil media. Plants are benefitted in terms of germination and growth, due to irrigation by textile effluents with proper dilution. The physical and biochemical properties of water streams along with aquatic organisms are impacted by these specific discharges, leading to even severe deterioration of particular living creatures. Pollutants released from various steps of textile processing have adverse effects on the environment, disturbing the food chain, ecosystem, and overall ecological balance.
\end{abstract}

\section{INTRODUCTION}

Industrialization reflects the economic improvement of countries (Sarayu \& Sandhya 2012) especially the textile industry is a boon for fiscal sustainability. Clothing is the second most fundamental need of human beings, agriculture being the prime essentials (Elango et al. 2017). Textile trade, especially exporting and importing, plays a prominent role in sustaining the economic growth of a country. According to the World Trade Statistical Review 2019, the share in the world export of textile (\%) of China, the European Union (28), Bangladesh, Vietnam, India, Turkey, Indonesia, Cambodia, and the United States of America in 2018 was 31.3, $28.4 \%, 6.4 \%, 6.2 \%, 3.3 \%, 3.1 \%, 1.8 \%, 1.6 \%$, and $1.2 \%$, respectively (WTO 2019). There are skilled and unskilled labor forces who work in different segments of the textile industry like dyeing, finishing, knit-composite, garments, printing, and washing factories. While the textile industry is scattered, it creates around 1 trillion dollars business, contributing to $7 \%$ of the total world exports, and about 35 million workers are engaged globally (Desore \& Narula 2018).

As 8,000 chemicals and a large volume of freshwater are used in the textile industry, this is one of the prime contributors to surface and groundwater pollution (Bhatia et al. 2017). The textile industry consumes a large volume of water in various processing stages, such as pretreatment, scouring, bleaching, dyeing, printing, washing, and finishing (Yin et al. 2017); however, the main pollution load originates from processes of dyeing and finishing (Lotito et al. 2014). Fig. 1 shows the influence of textile discharges on agricultural segments like soil, plants and fisheries.

Textile effluents discharged into surface water lead to contamination of water. The effluent acts as a pollutant because it disrupts the natural quality and composition of water and other environmental segments like soil and biodiversity. The wastewater generated in large volume by the textile industry is considered the most polluting effluents among all industrial effluents (Mani et al. 2019). Dyes and chemicals are prominent constituents in textile effluents that are not easily decomposable in the environment (Ghaly et al. 2014). Various types of chemicals such as wetting agents, sequestering agents, scouring, bleaching, dyeing, finishing, and printing chemicals are used in the pretreatment, dyeing, and finishing stages of textile processing. Approximately 280,000 tons of dyes are generated as effluents every year around the world (Maas \& Chaudhari 2005). Effluent discharged from textile processing into water bodies has sweeping implications on the environment as it contains numerous contaminants like solids, oils, metal complexes, organics, complex synthetic dyes, and remainders from different stages of fabric pretreatment and coloration (Bhatia et al. 2018). Textile effluent usually contains 


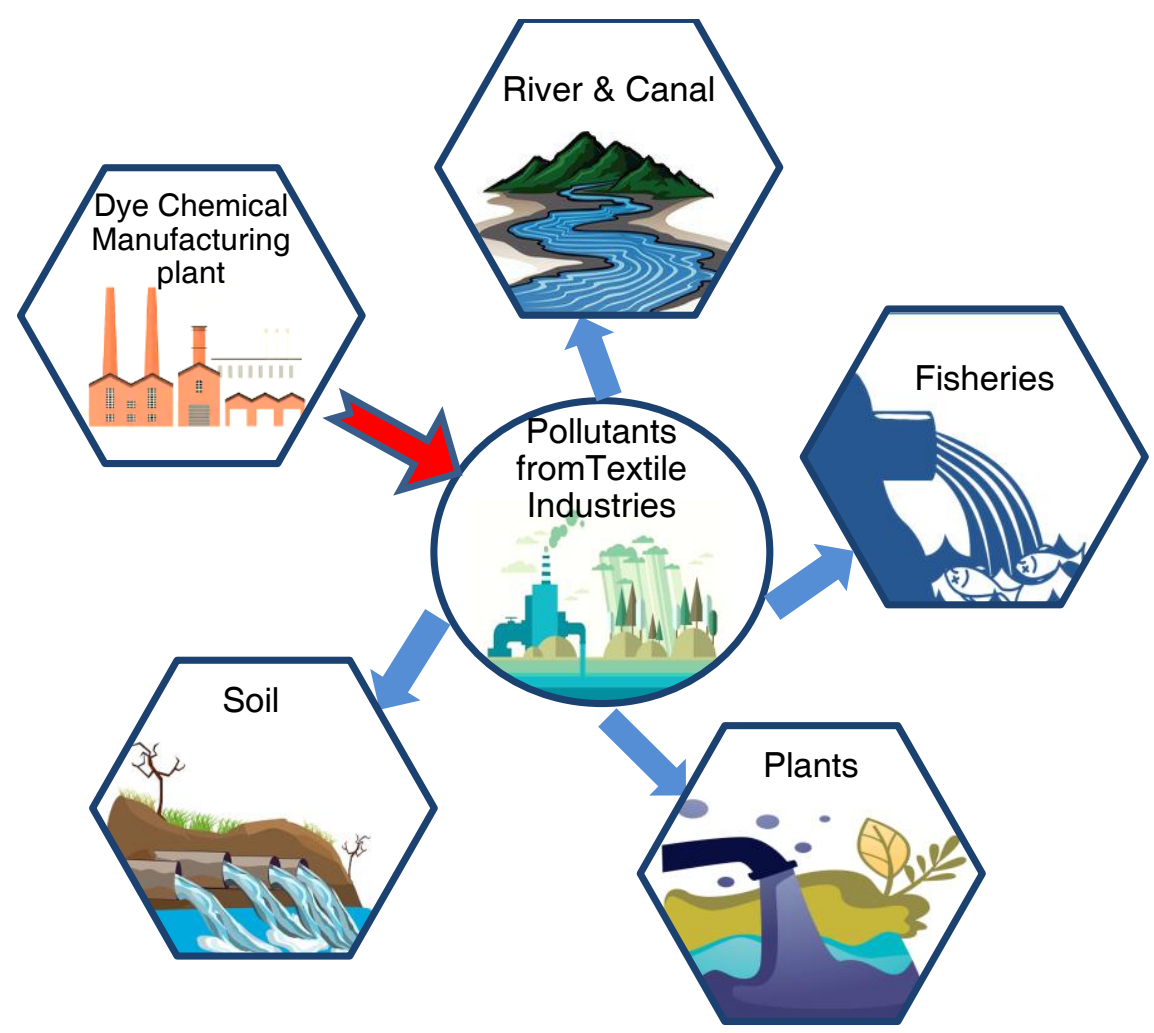

Fig. 1: Schematic diagram representing the impact of textile-based pollutants on soil, plant, water, and fisheries.

a higher concentration of total dissolved solids (TDS), total suspended solids (TSS), biochemical oxygen demand (BOD), and chemical oxygen demand (COD) when discharged into the environment (Mani et al. 2019).

Different categories of dyes like direct, acid, reactive, disperse, vat, basic, azoic, sulfur, etc. are used for the coloration and dyeing of different types of fabrics. Many of the dyes are usually metal salts. Heavy metals that occur in textile effluent are $\mathrm{As}, \mathrm{Ba}, \mathrm{Cd}, \mathrm{Cu}, \mathrm{Fe}, \mathrm{Hg}$, Os, Ni, and $\mathrm{Sb}$ (Nagajyoti et al. 2010). This paper summarizes the agricultural issues along with the characterization of the textile effluents.

\section{RATIONALE OF THE STUDY}

The effluents of different industries deteriorate the various components of the environment to a vast extent based on the composition of their respective discharges and the category of the industry. The deleterious impacts of these industries (mining, coal, oil, leather, tannery, distillery, chemicals, etc.) on surrounding nature have been reviewed in several studies. However, the attention given to the impact of textile effluents on agriculture such as plants, ecosystem, soil, fisheries and water remains limited. The human health-related issues, as well as the condition of air and water, have been discussed earlier in terms of textile releases. As agriculture plays a prime role in the economy, a review is done to analyze how textile-based pollutants disturb the different sectors of agriculture.

\section{IMPACT OF TEXTILE-BASED POLLUTANTS ON AGRICULTURE}

\section{Effects on Soil}

Soil acts as a basic source of agricultural growth and influences almost all parts of the life cycle (Emadodin et al. 2020). Around the world, wastewater irrigation is common in tropical and subtropical regions (Pandey et al. 2015). Irrigating the agricultural lands using different industrial wastewaters may alter the soil's physical, chemical, and biological properties (Mani et al. 2019). Several heavy metals such as chromium, copper, and zinc remain in high amounts in textile effluent, which may affect soil and the plant ecosystem. (Dey \& Islam 2015). Agricultural lands irrigated by industrial effluents may affect the soil's physical and chemical properties as well as soil fertility by augmenting the activity and diversity of microorganisms (Mani et al. 2019).

The dye bath auxiliaries having nitrogen and phosphorus (such as urea, ammonium acetate, ammonium sulfate, and 
phosphate) are the prime origin of nutrients in textile wastewater (Correia et al. 1994). Industrial effluent irrigation often increases the availability of nutrients for microbes (Jain et al. 2005, Li et al. 2015). The use of both treated and untreated wastewater has a temporal impact on the accumulation of heavy metals in soil (Khan et al. 2008, Ullah et al. 2012). Several researchers have stated that heavy metals accumulate in the soil because of the continuous watering of agricultural lands with industrial effluents (Hare et al. 2017, Chowdhary et al. 2018). Cai et al. (2012) observed that the concentrations of heavy metals such as $\mathrm{Cu}, \mathrm{Zn}, \mathrm{Ni}, \mathrm{Cr}, \mathrm{Pb}, \mathrm{Cd}$, As, and $\mathrm{Hg}$ in agricultural soils of Huizhou in China was found to be in the range of 1.65 to $99.8,16.8$ to $248.8,2.61$ to $112,1.12$ to 81.1 , 4.92 to $108.1,0.01$ to $1.12,1.1$ to $137.8,0.01$ to $3.39 \mathrm{mg} . \mathrm{kg}^{-1}$, respectively. However, the reference values recommended by the Chinese National Environmental Monitoring Centre (1990) for these heavy metals were $17,47.3,14.4,50.5,36,0.056$, 8.9 , and $0.078 \mathrm{mg} \cdot \mathrm{kg}^{-1}$, respectively. Because of the higher content of heavy metals in effluent sludge, a pre-treatment process for reducing the amount of heavy metal is mandatory before the sludge can be used as a soil conditioner or fertilizer in the agricultural soil (Islam et al. 2009). An effective effluent treatment system should be an integral part of the textile industry and be kept functional as well to protect agricultural land, water, and the surrounding environment.

\section{Effects on the Plants}

It is reported that African and Asian cities fulfill their demand (50\%) for vegetables from agricultural lands irrigated with wastewater (Bjuhr 2007). The amount of nitrogen in the textile effluent reported by Begum et al. (2018) in two regions of Narayanganj and Gazipur, Bangladesh was high - about $0.05 \%$ and $0.07 \%$ respectively. There were six treatments of different effluent levels including different proportions of fresh water and Recommended Dose of Fertilizer (RDF).

It was observed that all the treatments showed a significant positive effect on the yield parameters of jute vegetables over the control on agricultural soils. However, in contaminated soils, effluent irrigation showed a negative effect over the control (Begum et al. 2018). Ganesan and Chellappan (2018) studied the growth of Sea Marigold planted in soil irrigated with partially diluted textile effluents. The result demonstrated a positive effect on plant shoot length and root length, plant biomass, chlorophyll content, and carotenoid of three different cultivars of wheat, when compared with raw effluent irrigated plants. Moreover, the responding plant exhibited maximum development and growth because of the absence of textile effluent. At low concentrations, textile effluent did not show an impeding effect on seed germination, whereas seeds germinated in undiluted effluents did not survive for a longer

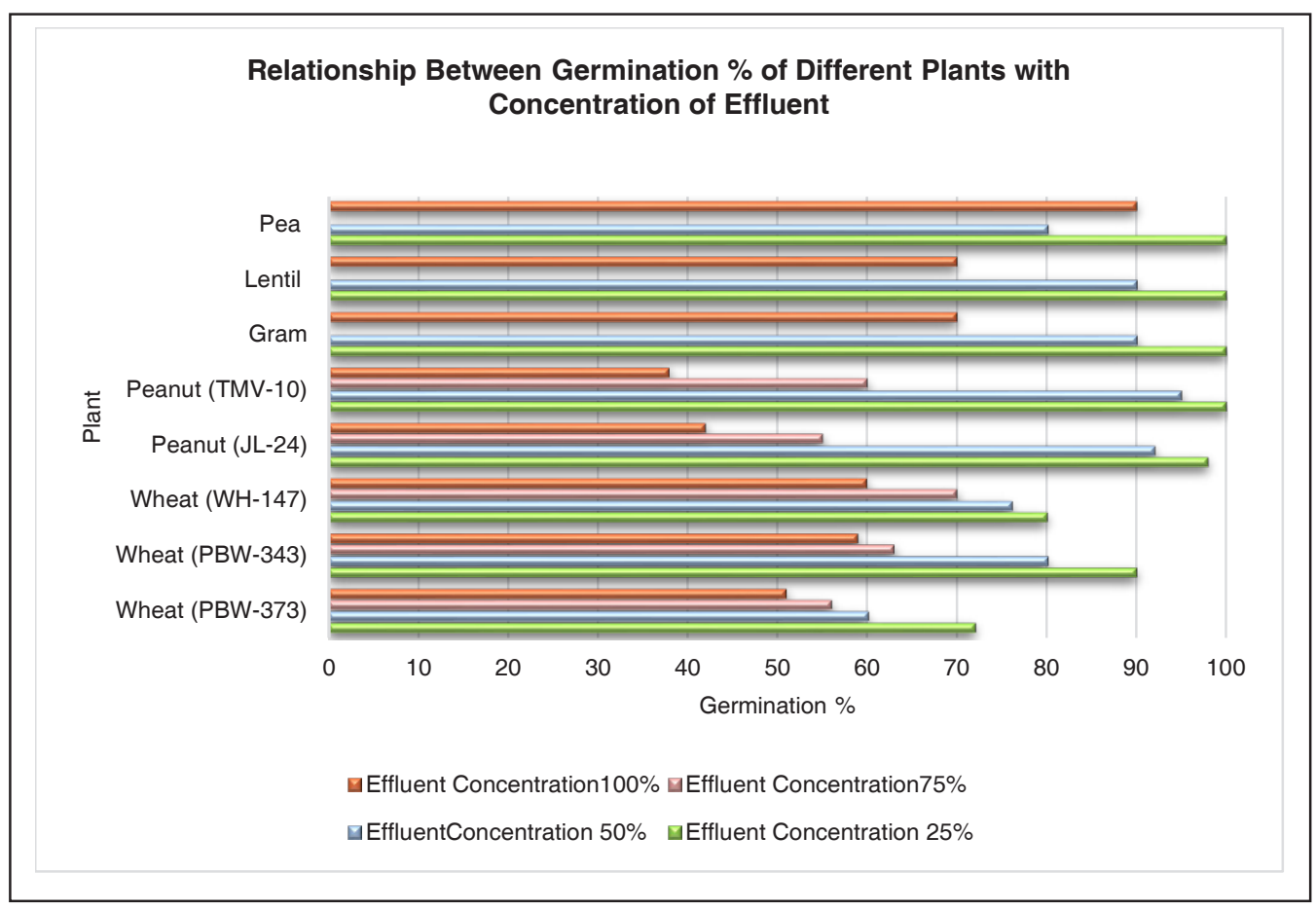

Fig. 2: Effect of various concentration of textile effluent on germination percentage (\%) of different plants (Kaushik et al. 2005, Saravanamoorthy \& Kumari 2007, Gufrankhan et al. 2011). 
period (Kaushik et al. 2005). The relationship between the germination of different plants with various concentrations of textile effluent is depicted in Fig. 2, based on data collected from several related research works.

Several other studies reported similar outcomes on germination, biomass, chlorophyll pigments, and root growth of peas, lentil, and gram seedlings by textile effluents when irrigated in low concentrations, compared to adverse impact on plants when irrigated with highly concentrated textile effluents (Gufrankhan et al. 2011). The usage of textile wastewater on planting and irrigation of two varieties of peanut exhibited an increased chlorophyll content, growth yield, and germination positively contributing to root length and shoot length, etc. (Saravanamoorthy \& Kumari 2007).

Metals play an essential role in the formation of dyes, and copper, zinc, chromium, lead, cobalt, nickel, and manganese are commonly used heavy metals in several dyes (Madhav et al. 2018). Heavy metals exert an impending threat to the food security of the contaminated area and show precarious influence on the ecosystem (Lu et al. 2012, Mombo et al. 2016). As noted by Gopalakrishnan and Jeyadoss (2011), textile effluent contains a very high concentration of zinc, copper, and cadmium at 4.56, 2.69, and $2.49 \mathrm{mg} . \mathrm{L}^{-1}$, respectively, beyond their acceptable limits (Zn: 0.5 g mg. $\mathrm{L}^{-1}, \mathrm{Cu}: 0.05 \mathrm{mg} . \mathrm{L}^{-1}, \mathrm{Cr}: 0.05$ $\left.\mathrm{mg} . \mathrm{L}^{-1}\right)$ and causing numerous environment-related problems. Though copper is a necessary micronutrient required in a small quantity for the growth of the plant, yet toxicity is imposed upon plants when assimilated in high amounts (Mahmood \& Islam 2006). Likewise, cadmium displays toxicity by hindering the growth of plants (Hu et al. 2013).

In the case of soil-plant interaction, high concentrations of heavy metals in the soil showed adverse effects on different plants such as alfalfa, lettuce, radish, and alpine pennycress, but at low concentrations, their effects were moderate on those plants (Guala et al. 2010). As industrial effluent acts as a prime key source for accretion of heavy metals in crops, prior treatment is necessary for the effluent before release into the surrounding environment (Chowdhary et al. 2018). Toxic metal ions and nutrients from the soil reach the tissues of the plant (DalCorso et al. 2013) and an extreme accumulation of heavy metals in plant tissue impact seed germination, root elongation, plant biomass, and chlorophyll biosynthesis and consequently, affect crop productivity (Shahid et al. 2015).

Fresh and dry biomass of plants decreased with an increase in the concentration of textile effluents; a high concentration of the effluent inhibited the survival of plants (Rehman et al. 2009). Textile wastewater can be used safely for the irrigation of plants and crops after appropriate treatment of the effluent if there is a shortage of water for irrigation (Rehman et al. 2009). Most of the studies have shown that the growth and development of other morphological parameters of plants improved if the plants are irrigated by partially diluted effluents. In contrast, the highly concentrated textile effluent negatively impacted the plants.

\section{Effects on Water and Fisheries}

The release of textile effluents, whether solid, liquid, or gaseous, affected the aquatic ecosystem by decreasing the penetration of sunlight and hence diminishing the photosynthesis rates and raising the biological oxygen in water (Kant 2012, Singh et al. 2015). Ahmed et al. (2011) conducted studies on the Buriganga and Karnatoli rivers near Dhaka, Bangladesh at the proximity of the textile industries and reported that the values of physicochemical properties of textile effluent like BOD, salinity, TDS, TSS, sodium, potassium, calcium, iron, phosphate, chloride, nitrite and nitrate were 46.9 to $58.5,0.75$ to $1.03,984$ to $1148,872.75$ to $1282.4,390$ to $411.1,12.4$ to $31,37.21$ to $54.82,0.12$ to $0.18,18.25$ to $19.88,72.21$ to $135.87,0.07$ to 0.74 and 0.47 to $1.02 \mathrm{mg} . \mathrm{L}^{-1}$, respectively. These values were beyond the acceptable limit for open water recommended by the Department of Environment, Bangladesh, and might threaten the living organisms in the surface water and ecosystem of Buriganga and Karnatoli river (Ahmed et al. 2011).

The constituents of natural water streams may have an increased possibility to be solubilized because of the high $\mathrm{pH}$ in effluents and aquatic life is hampered due to these high $\mathrm{pH}$ values (Younas et al. 2017). Highly alkaline condition is not suitable for the existence of living organisms in the water bodies. Besides heavy metals, organic pigments, and dyes, for example, C.I. Pigment Yellow-12, C.I. Disperse Yellow-7, C.I. Direct Yellow-1, etc., salt, acid, alkalis, bleaching, and finishing agent have an adverse impact on the health of living things to a large scale (Imtiazuddin et al. 2012). The pH value of textile effluent collected from the release point of seven different textile mills situated in Pakistan was in the range of 7.5 and 11.5, whereas the value recommended by National Environmental Quality Standards (NEQS), Pakistan was 6 to 9 (Imtiazuddin et al. 2012).

The physical and biochemical properties of water and aquatic life are interlinked and impact one another, directly or indirectly (Sanga \& Sirsat 2016). High temperature reduces the solubility of gases in water that ultimately increases BOD or COD. Short-term temperature variation in waterbodies near textile and dyeing industries might create problems for fish egg hatching and even lead to death, thus affecting the fish population (Roy et al. 2010). The excessive levels of TSS in water systems can have a significant detrimental impact on the physical, chemical, and biological properties of the waterbodies (Bilotta \& Brazier 2008). The changes 
in the water system due to the discharge of effluent impair the osmoregulatory mechanism of aquatic lives and make water unsuitable for the intended use (Kaur \& Soodan 2020).

Textile industries around the world consume more than 10,000 tons of dyes each year. 100 tons of toxic textile effluents are discharged into water resources/bodies every year that can damage the ecosystem (Iqbal \& Ashiq 2007, Dizge et al. 2008). For instance, zinc displays harmful effects on the initial stages of aquatic life when it is present in large concentrations in water. Furthermore, exposure to nickel for a longer duration can reduce body weight, damage the heart and liver of aquatic species, and also cause skin irritation (Imtiazuddin et al. 2014). Thus, in consequence, contaminated natural water bodies have a deadly impact on fishes and inhibit the growth of microorganisms (Puvaneswari et al. 2006).

Soni et al. (2006) conducted a study to observe the toxicity of textile dye wastewater on a freshwater fish, Gambusia affinis, and found noticeable changes in the shape and variation of red blood cells. Also because of high BOD and COD values of dyes, aquatic organisms and fish confront toxicity (Al Prol 2019). When textile wastewater reaches the water stream, the amount of total dissolved solids and total suspended solids increases as unfixed dyes, remnants of starch, different finishing chemicals, agents, and salts are carried along with the effluents, and further, these fragments increase the salinity of the water. Because of high salinity in the freshwater system, contaminated water has a harmful impact on organisms of water bodies, especially exposing osmotic imbalance and hampering homeostasis in aquatic lives (Ahmed et al. 2011). It is reported that mortality of Tilapia was increased with the increase of concentration of textile effluent in Lake Hawassa, Southern Ethiopia. Berehanu et al. (2015) indicated the mortality of that fish was about 16.1, 65, 86.8 , and $88.7 \%$ at $1 \%, 5 \%, 10 \%$, and $20 \%$, concentration levels of textile effluents, respectively. Other scientists (Table 1) also reported mortality rates of tilapia fish.
So, textile effluent discharge exerted a potential threat to the existence of aquatic life especially fish (Berehanu et al. 2015). Muley et al. (2007) carried out a study on Labeo rohita with exposure to effluent around Kolhapur, India. In the acute toxicity (96 hr) experiment, the fingerlings of freshwater fish Labeo rohita were exposed to tannery, electroplating, and textile mill effluents. It was found that electroplating effluent was more toxic than tannery and textile mill wastes. After acute toxicity experiments for different industrial effluents, various tissues viz. gill, liver, muscle and kidney were obtained separately. The glycogen content in all the tissues decreased considerably upon acute toxicity of three industrial effluents. The total protein content decreased in all tissues in three effluents. In general total lipid content decreased in all tissues after acute exposure when compared to control group. The results obtained in the present study showed that, the industrial effluents from tannery, electroplating and textile mills caused marked depletion in biochemical composition in various tissues of the fish Labeo rohita after acute exposure.

Using the acute toxicity (96 hr) and chronic (30 days) exposure experiment, Nikalje et al. (2011) investigated the Labeo rohita in the polluted Panchganga river near Kolhapur, India. There was a remarkable decrement in protein, total glycogen, and lipid content in all tissues of Labeo rohita because of the presence of heavy metals in high amounts (Nikalje et al. 2011). The decline was more significant at higher concentrations of effluent than lower concentrations. In summary, proper dilution of textile effluent before discharge is a prerequisite to lessen the negative impact on fisheries.

\section{CONCLUSION}

The textile industry releases diverse and high amounts of pollutants into the environment, which consequently affects different segments of the agricultural ecosystem including soil, plants, water, and fisheries. Thus, pollutants disrupt the food chain, ecosystem, and agricultural productivity over

Table 1: Effect of concentration of textile effluent on mortality rate of Tilapia (Oreochromis niloticus)

\begin{tabular}{|llcl|}
\hline & & Mortality \% of Tilapia (Oreochromis niloticus) \\
\hline Concentration of Effluent \% & 1 day & 4 days & 7 days \\
\hline 1 & - & - & 16.1 \\
5 & - & - & 65 \\
10 & 23 & 10 & 86.8 \\
20 & 64 & 20 & 88.7 \\
30 & - & 50 & - \\
40 & - & 70 & - \\
100 & - & 100 & - \\
\hline
\end{tabular}


time. To maintain the ecological balance, it is important to take necessary initiatives with utmost importance. Imparting cost-effective and eco-friendly chemicals, techniques and methods might be a better option to combat environmental degradation. An effective effluent treatment plant should be an integral part of each textile factory to minimize pollution. The law enforcing bodies and monitoring committees of different countries can play a significant role to ameliorate the damage to agriculture as well as other organisms due to textile effluent pollution by enacting stringent laws, rules, and regulations for protecting the environment from textile-based pollution.

\section{REFERENCES}

Ahmed, M.K., Das, M., Islam, M.M.,Akter M.S. and Islam,M. 2011. Physico-chemical properties of tannery and textile effluents and surface water of river Buriganga and Karnatoli, Bangladesh. World Appl. Sci. J., 12: 152-159

Al Prol, A.E. 2019. Study of environmental concerns of dyes and recent textile effluents treatment technology: a review. Asian J. Fish Aquat. Res., 3: 1-18.

Begum, M., Gani, M.N. and Alam, M.D. 2018. Effect of textile effluent on the yield of jute leaves (Corchorus capsularis) in winter season. J. Biodivers. Conserv. Bioresour. Manag., 4: 53-60.

Berehanu, B., Lemma, B. and Tekle-Giorgis Y. 2015. Chemical composition of industrial effluents and their effect on the survival of fish and eutrophication of Lake Hawassa, Southern Ethiopia. J. Environ. Prot. (Irvine, Calif), 06: 792-803.

Bhatia, D., Sharma, N.R., Singh, J. and Kanwar, R.S. 2017. Biological methods for textile dye removal from wastewater: A review. Crit. Rev. Environ. Sci. Technol., 47: 1836-1876.

Bilotta, G.S. and Brazier, R.E. 2008. Understanding the influence of suspended solids on water quality and aquatic biota. Water Res., 42: 2849-2861.

Bjuhr, J. 2007. Trace metals in soils irrigated with wastewater in a periurban area downstream Hanoi City, Vietnam. Dissertation, Swedish University of Agricultural Sciences.

Cai, L., Xu, Z., Ren, M., Guo, M., Hu, X., Hu, G., W. H. and Peng, P. 2012. Source identification of eight hazardous heavy metals in agricultural soils of Huizhou, Guangdong Province, China. Ecotoxicol. Environ. Saf.,78: 2-8.

Chavan, R.B. 2001. Indian textile industry: Environmental issues. Indian J. Fibre. Text. Res. 26: 11-21.

China National Environmental Monitoring Centre (CNEMC) 1990. Soil element background values in China. Beijing: China Environmental Science Press (in Chinese), pp. 330-483.

Chowdhary, P., Raj, A. and Bharagava, R.N. 2018. Environmental pollution and health hazards from distillery wastewater and treatment approaches to combat the environmental threats: A review. Chemosphere, 194: 229-246.

Correia, V.M., Stephenson, T. and Judd, S.J. 1994. Characterisation of textile wastewaters: A review. Environ. Technol., 15: 917-929.

DalCorso, G., Fasani, E. and Furini, A. 2013. Recent advances in the analysis of metal hyperaccumulation and hypertolerance in plants using proteomics. Front. Plant Sci., 4: 1-8.

Desore, A. and Narula, S.A. 2018. An overview on corporate response towards sustainability issues in textile industry. Environ. Dev. Sustain., 20: $1439-1459$.

Dey, S. and Islam, A. 2015. A review on textile wastewater characterization in Bangladesh. Resour. Environ., 5: 15-44.
Dizge, N, Aydiner, C, Demirbas, E., Kobya, M. and Kara, S. 2008. Adsorption of reactive dyes from aqueous solutions by fly ash: Kinetic and equilibrium studies. J. Hazard Mater., 150: 737-746.

Elango, G., Rathika, G. and Elango, S. 2017. Physico-chemical parameters of textile dyeing effluent and its impacts with case study. Int. J. Res. Chem. Environ., 7: 17-24.

Emadodin, I., Reinsch, T., Rotter, A.,Orlando-Bonaca, M., Taube, F. and Javidpour, J. 2020. A perspective on the potential of using marine organic fertilizers for the sustainable management of coastal ecosystem services. Environ. Sustain., 3: 105-115.

Ganesan, S. and Chellappan, R.K. 2018. Morphological, biochemical, and antioxidant enzyme adaptation of Suaeda maritima growing in textile dye effluent irrigated soil. Indian J. Plant Physiol., 23: 128-139.

Ghaly, A., Ananthashankar, R., Alhattab, M. and Ramakrishnan, V. 2014. Production, characterization and treatment of textile effluents: a critical review. J. Chem. Eng. Process Technol., 05: 1-18.

Gopalakrishnan, K. and Jeyadoss, T. 2011. Comparative study on biosorption of $\mathrm{Zn}(\mathrm{II}), \mathrm{Cu}(\mathrm{II})$, and $\mathrm{Cr}(\mathrm{VI})$ from textile dye effluent using activated rice husk and activated coconut fiber. Indian J. Chem. Technol., 18: 61-66.

Guala, S.D., Vega, F.A. and Covelo, E,F. 2010. The dynamics of heavy metals in plant-soil interactions. Ecol. Modell., 221: 1148-1152.

Gufrankhan, M. Daniel, G. and Konjit, M. 2011. Impact of textile wastewater on seed germination and some physiological parameters in pea (Pisum sativum L.), lentil (Lens esculentum L.), and gram (Cicer arietinum L.). Asian J. Plant Sci., 10: 269-273.

Hare, V., Chowdhary, P. and Baghel, V.S. 2017. Influence of bacterial strains on Oryza sativa grown under arsenic tainted soil: Accumulation and detoxification response. Plant Physiol. Biochem., 119:93-102.

Hu, Y.F., Zhou, G. and Na, X.F. 2013. Cadmium interferes with maintenance of auxin homeostasis in Arabidopsis seedlings. J. Plant Physiol., 170: 965-975.

Imtiazuddin, S.M. and Mumtaz, M. and Mallick, K.A. 2012. Pollutants of wastewater characteristics in textile industries. J. Basic Appl. Sci., 8: 554-556.

Imtiazuddin, S.M., Mumtaz, M. and Ahmed, T. 2014. Physico-chemical analysis and heavy metals concentration in textile effluent in Karachi region of Pakistan. Glob. J. Environ. Sci. Technol., 2: 71-74.

Iqbal, M.J. and Ashiq, M.N. 2007. Adsorption of dyes from aqueous solutions on activated charcoal. J. Hazard Mater., 139: 57-66.

Islam, M., Halim, M.A., Safiullah, S., Hoque, S.M. and Islam, M.S. 2009. Heavy metal ( $\mathrm{Pb}, \mathrm{Cd}, \mathrm{Zn}, \mathrm{Cu}, \mathrm{Cr}, \mathrm{Fe}$, and $\mathrm{Mn}$ ) content in textile sludge in Gazipur, Bangladesh. Res. J. Environ. Sci., 3: 311-315.

Jain, R.K., Kapur, M., Labana, S., Lal, B., Sarma, P.M., Bhattacharaya, D. and Thakur, S. 2005. Microbial diversity: Application of microorganisms for the biodegradation of xenobiotics. Curr. Sci., 89: 101-112.

Kant, R. 2012. Textile dyeing industry an environmental hazard. Nat. Sci., 4: 22-26

Kaur, S., and Soodan, M. 2020. Literature review on the effect of textile and paper mill effluents on aquatic organisms. Sustain. Humanosph., 16: 1528-1541.

Kaushik, P., Garg, V.K. and Singh, B. 2005. Effect of textile effluents on growth performance of wheat cultivars. Bioresour. Technol., 96: 1189-1193.

Khan, S., Cao, Q., Zheng, Y.M. Huang, Y.Z. and Zhu, Y.G. 2008. Health risks of heavy metals in contaminated soils and food crops irrigated with wastewater in Beijing, China. Environ. Pollut., 152: 686-692.

Li, C., Zhang, Z., Li, Y. and Cao, J. 2015. Study on dyeing wastewater treatment at high temperature by MBBR and the thermotolerant mechanism based on its microbial analysis. Process Biochem., 50: 1934-1941.

Lotito, A.M., De Sanctis, M., Rossetti, S., Lopez, A. and Di Iaconi,C. 2014. On-site treatment of textile yarn dyeing effluents using an integrated biological-chemical oxidation process. Int. J. Environ. Sci. Technol., 11: 623-632. 
Lu, A., Wang, J., Qin, X., Wang, K., Han, P. and Zhang, S. 2012. Multivariate and geostatistical analyses of the spatial distribution and origin of heavy metals in the agricultural soils in Shunyi, Beijing, China. Sci. Total Environ., 425: 66-74.

Maas, R. and Chaudhari, S. 2005. Adsorption and biological decolorization of azo dye Reactive Red 2 in semicontinuous anaerobic reactors. Process Biochem., 40: 699-705.

Madhav, S., Ahamad, A., Singh, P. and Mishra, P.K. 2018. A review of textile industry: wet processing, environmental impacts, and effluent treatment methods. Environ. Qual. Manag., 27: 31-41.

Mahmood, T. and Islam, K.R. 2006. Response of rice seedlings to copper toxicity and acidity. J. Plant. Nutr., 29: 943-957.

Mani, S., Chowdhary, P. and Hare, V. 2019. Industrial Effluents: Impact on Agricultural Soils and Microbial Diversity. In: Varma, A., Tripathi, S. and Prasad, R. (eds) Plant Biotic Interactions. Springer Nature, Switzerland AG, pp 43-60

Mombo, S., Foucault, Y., Deola, F. Gaillard, I., Goix, S., Shahid, M., Schreck, E., Pierart, A. and Dumat,C. 2016. Management of human health risk in the context of kitchen gardens polluted by lead and cadmium near a lead recycling company. J. Soils Sediments, 16: 1214-1224.

Muley, D.V., Karanjkar, D.M. and Maske, S.V. 2007. Impact of industrial effluents on the biochemical composition of fresh water fish Labeo rohita. J. Environ. Biol., 28: 245-249.

Nagajyoti, P., Lee, K. and Sreekanth, T. 2010. Heavy metals occurrence and toxicity for plants: A review. Environ. Chem. Lett., 8: 199-216.

Nikalje, S.B., Muley, D.V., Pailwan, S.M. and Angadi, I.F. 2011. Biochemical alterations in different tissues of a freshwater major carp labeo rohita after acute and chronic exposure to textile mill effluent (TME). In: International conference on climate change, forest resource, and environment. The Ecoscan, Thiruvananthapuram, pp 341-345.

Pandey R., Singh, J. and Ababa, A. 2015. Effect of textile factory effluent irrigation on productivity of the wheat crop. Int. J. Sci. Environ. Technol., 4: 727-736.

Puvaneswari, N., Muthukrishnan, J. and Gunasekaran, P. 2006. Toxicity assessment and microbial degradation of azo dyes. Indian J. Exp. Biol., 44: 618-626

Rehman, A., Bhatti, H.N. and Athar, H.U.R. 2009. Textile effluents affected seed germination and early growth of some winter vegetable crops: a case study. Water Air Soil Pollut., 198:155-163.

Roy, R., Fakhruddin, A., Khatun, R., Islam, M.S., Ahsan, M.A. and Negar, A.J.M.T. 2010. Characterization of textile industrial effluents and its effects on aquatic macrophytes and algae. Bangladesh J. Sci. Ind. Res., 45: 79-84.

Sanga, R.M. and Sirsat, P. 2016. Toxicity of industrial effluent on fry of exotic carp, Cyprinus carpio. J. Environ. Res. Dev., 10: 729-733.

Saravanamoorthy, M.D. and Kumari, B.D.R. 2007. Effect of textile wastewater on morphophysiology and yield on two varieties of peanut (Arachis hypogaea L .). J. Agric. Technol. Eff., 5: 1432-1435.

Sarayu, K. and Sandhya, S. 2012. Current technologies for biological treatment of textile wastewater: A review. Appl. Biochem. Biotechnol., 167: 645-661.

Shahid, M., Khalid, S. and Abbas, G. 2015. Heavy metal stress and crop productivity. In: Hakeem, K. R. (ed), Crop production and global environmental issues. Springer International Publishing Switzerland, pp 1-15.

Singh, A.L., Chaudhary, S., Kayastha, A.M. and Yadav, A. 2015. Decolorization and degradation of textile effluent with the help of Enterobacter asburiae. Indian J. Biotechnol., 14: 101-106.

Soni, P., Sharma, S. and Sharma, S. 2006. A comparative study on the toxic effects of textile dye wastewaters (untreated and treated) on mortality and RBC of a freshwater fish Gambusia affinis (Baird and Gerard). J Environ. Biol., 27: 623-628.

Ullah, H., Khan, I. and Ullah, I. 2012. Impact of sewage-contaminated water on soil, vegetables, and underground water of peri-urban Peshawar, Pakistan. Environ. Monit. Assess., 184:6411-6421.

WTO. 2019. World Trade Organization. World Trade Stat. Rev. https://www. wto.org/english/res_e/statis_e/wts2019_e/wts2019_e.pdf. Accessed 25 Jun 2020

Yin, H., Guo, H., Qiu, P., Yi, L. and Li, J. 2017. Case analysis on textile wastewater subjected to combined physicochemical-biological treatment and ozonation. Desalin. Water Treat., 66: 140-148.

Younas, U., Iqbal, S., Saleem, A. Iqbal, M., Nazir, A., Noureen, S., Mehmood, K. and Nisar, N. 2017. Fertilizer industrial effluents: Physicochemical characterization and water quality parameters evaluation. Acta. Ecol. Sin., 37: 236-239. 